\title{
Hydrogen Peroxide Stimulates Rat Colonic Prostaglandin Production and Alters Electrolyte Transport
}

\author{
S. Selim Karayalcin, Christopher W. Sturbaum, Joseph T. Wachsman, Jih-Ho Cha, and Don W. Powell \\ Department of Medicine and Core Center in Diarrheal Diseases, University of North Carolina at Chapel Hill, \\ Chapel Hill, North Carolina 27599
}

\begin{abstract}
The changes in short circuit current (electrogenic $\mathrm{Cl}^{-}$secretion) of rat colon brought about by xanthine/xanthine oxidase in the Ussing chamber were inhibited by catalase and diethyldithiocarbamate, but not by superoxide dismutase. These results, the reproduction of the response with glucose/glucose oxidase and with exogenous $\mathrm{H}_{2} \mathrm{O}_{2}$, and the lack of effect of preincubation with deferoxamine or thiourea implicate $\mathrm{H}_{2} \mathrm{O}_{2}$, and not $\mathrm{O}_{\bar{i}}$ or $\mathrm{OH}$, as the important reactive oxygen metabolite altering intestinal electrolyte transport. $1 \mathrm{mM} \mathrm{H}_{2} \mathrm{O}_{2}$ stimulated colonic PGE $_{2}$ and $\mathbf{P G I}_{2}$ production 8- and 15-fold, respectively, inhibited neutral $\mathrm{NaCl}$ absorption, and stimulated biphasic electrogenic $\mathrm{Cl}$ secretion with little effect on enterocyte lactic dehydrogenase release, epithelial conductance, or histology. $\mathrm{Cl}^{-}$secretion was reduced by cyclooxygenase inhibition. Also, the $\mathrm{Cl}^{-}$secretion, but not the increase in prostaglandin production, was reduced by enteric nervous system blockade with tetrodotoxin, hexamethonium, or atropine. Thus, $\mathrm{H}_{2} \mathrm{O}_{2}$ appears to alter electrolyte transport by releasing prostaglandins that activate the enteric nervous system. The change in short circuit current in response to Iloprost, but not $\mathbf{P G E}_{2}$, was blocked by tetrodotoxin. Therefore, $\mathbf{P G I} \mathbf{2}_{2}$ may be the mediator of the $\mathrm{H}_{2} \mathrm{O}_{2}$ response. $\mathrm{H}_{2} \mathrm{O}_{2}$ produced in nontoxic concentrations in the inflamed gut could have significant physiologic effects on intestinal water and electrolyte transport. ( $J$. Clin. Invest. 1990. 86:60-68.) Key words: intestinal secretion • inflammation • enteric nervous system • prostaglandin • oxygen radical
\end{abstract}

\section{Introduction}

Reactive oxygen metabolites (ROMs) ${ }^{1}$ are oxygen-centered free radicals or their reduction products $(1-3)$. The reactivity of oxygen can be increased by excitation or reduction. An

This study was presented in part at the 1988 Annual Meeting of the American Gastroenterological Association, and has appeared in abstract form (1988. Gastroenterology. 94:A216; and 1988. Gastroenterology. 94:A217).

Address reprint requests to Dr. D. W. Powell, CB \#7005, 3029 Old Clinic Bldg., University of North Carolina, Chapel Hill, NC 275997005.

Received for publication 17 April 1989 and in revised form 17 January 1990.

1. Abbreviations used in this paper: ATR, atropine; CAT, catalase; DDTC, diethyldithiocarbamate; DES, deferoxamine; ENS, enteric nervous system; G, glucose; GO, glucose oxidase; HEX, hexametho-

J. Clin. Invest.

(c) The American Society for Clinical Investigation, Inc. 0021-9738/90/07/0060/09 \$2.00

Volume 86, July $1990,60-68$ excitation product (singlet oxygen) results from an absorption of energy that shifts one of the unpaired electrons of the molecule to an orbit of higher energy with an inversion of its spin. Singlet oxygen may not exist to any extent in biological tissues; however, the reduction products certainly do. The reduction of oxygen by the sequential addition of four electrons creates two products, superoxide $\left(\mathrm{O}_{\overline{2}}\right)$ and hydroxyl radical $\left(\mathrm{OH}^{\circ}\right)$, which are free radicals (molecules containing an odd number of electrons, rendering them chemically reactive) as well as hydrogen peroxide $\left(\mathrm{H}_{2} \mathrm{O}_{2}\right)$, a potent oxidant. The length of time that $\mathrm{H}_{2} \mathrm{O}_{2}$ can exist in tissue and the distance to which it can diffuse (much like water) are dependent on the presence of protective enzymes in the tissue (catalase [CAT] and glutathione peroxidase) (1-3). Therefore, $\mathrm{H}_{2} \mathrm{O}_{2}$, the least reactive of the metabolites, has the longest half-life and potentially is capable of important biological effects.

The sources of ROMs in the intestine include the mitochondrial and microsomal transport chains, those created by oxidant enzymes such as xanthine oxidase (XO) and the cyclooxygenase and lipooxygenase enzymes of AA metabolism, and the respiratory burst of phagocytic cells (2). Some believe that the most important sources of ROMs in the intestine are resident or newly arrived phagocytes (3). Upon stimulation, a transmembrane electron transport system utilizes NADPH on the cytoplasmic side of the phagocytic cell membrane to reduce $\mathrm{O}_{2}$ to $\mathrm{H}_{2} \mathrm{O}_{2}$. Potentially, millimolar concentrations of $\mathrm{H}_{2} \mathrm{O}_{2}$ may be secreted in the immediate vicinity of target cells $(2,4)$. The important stimulants of the formation of ROMs in the intestine, consequently, are those that activate phagocytes (3).

Recent studies in our laboratory have shown that ROMs are capable of altering electrolyte transport in the in vitro rat colon mounted in the Ussing chamber (5). These results led us to postulate that while either ROMs or prostaglandins released by ROMs may have a direct effect on the enterocyte, some cyclooxygenase products like $\mathrm{PGI}_{2}(6,7)$ may modulate rat colonic electrolyte transport primarily by activating the enteric nervous system (ENS).

It was unclear from our previous studies, however, which ROM was actually causing this transport response. The xanthine $(\mathrm{X}) / \mathrm{XO}$ reaction creates $\mathrm{O}_{\overline{2}}^{\overline{2}}$, which is spontaneously and enzymatically dismutated to $\mathrm{H}_{2} \mathrm{O}_{2}$, as well as $\mathrm{H}_{2} \mathrm{O}_{2}$ itself. In the presence of iron, $\mathrm{H}_{2} \mathrm{O}_{2}$ can also be metabolized to $\mathrm{OH}^{-}$(the Haber-Weiss or Fenton reaction) $(1,3)$. In this investigation we determined that $\mathrm{H}_{2} \mathrm{O}_{2}$ is the $\mathrm{ROM}$ responsible for the alteration in transport and characterized the colonic electrolyte transport response to this oxidant.

nium; $\mathrm{H}_{2} \mathrm{O}_{2}$, hydrogen peroxide; INDO, indomethacin; Isc, short circuit current; $\mathrm{LDH}$, lactate dehydrogenase; $\mathrm{O}_{\overline{2}}^{\overline{2}}$, superoxide; $\mathrm{OH}$; hydroxyl radical; PXM, piroxicam; ROM, reactive oxygen metabolite; TH, thiourea; TTX, tetrodotoxin; $\mathrm{X}$, xanthine; $\mathrm{XO}$, xanthine oxidase. 


\section{Methods}

Preparation of intestine. Male Sprague-Dawley rats (250-350 g) with free access to normal rat chow and water were killed by cervical dislocation. The colon was removed and opened along its mesenteric border and rinsed in ice-cold Ringer solution and the serosa and muscularis propria were removed as previously described $(5,8)$. A 2-cm section of the tissues was fixed with buffered $4 \%$ formaldehyde- $10 \%$ gluteraldehyde and stained with hematoxylin and eosin or with diamine silver for histological demonstration of mucosal and neural structure, respectively (see Fig. $8 \mathrm{~A}$ ). These studies revealed that the plane of division was at the innermost aspect of the circular muscularis propria layer, leaving the muscularis mucosae and submucosal nerve plexus intact. This preparation, consisting of epithelium, lamina propria, muscularis mucosae, and submucosa, was mounted in Ussing-type chambers ( 0.5 $\mathrm{cm}^{2}$ exposed surface area) and bathed in 5-10 $\mathrm{ml}$ of glucose-Ringer solution on each side. The glucose-Ringer solution, $\mathrm{pH} 7.4$ when gassed with $95 \% \mathrm{O}_{2} / 5 \% \mathrm{CO}_{2}$, contained $10 \mathrm{mM}$ glucose and ions in the following concentrations (in $\mathrm{mM}$ ): $\mathrm{Na} 140 ; \mathrm{Cl} 119.8 ; \mathrm{K} 5.2 ; \mathrm{HCO}_{3} 25$; Ca $1.2 ; \mathrm{Mg} 1.2 ; \mathrm{HPO}_{4} 2.4 ;$ and $\mathrm{H}_{2} \mathrm{PO}_{4}$ 0.4. Solutions were circulated by gas lift and maintained at $37^{\circ} \mathrm{C}$ in water-jacketed reservoirs.

Four to six tissues were obtained from distal colon for experiments in which one tissue served as a control (stimulated with the agonist), while the others were used to test the effects of inhibitors. Concentration-response curves were obtained by adding the agonists or inhibitors to the serosal solution of four tissues mounted from a single animal. At various times, 1-ml samples of serosal bathing solutions were placed into polypropylene vials, gassed with argon, and stored at $-20^{\circ} \mathrm{C}$ for future radioimmunoassay of various eicosanoids. In other experiments, aliquots of either the mucosal or serosal solutions were taken for measurement of lactic dehydrogenase (LDH) activity or for concentrations of $\mathrm{O}_{\overline{2}}$ or $\mathrm{H}_{2} \mathrm{O}_{2}$. To assess the effect of oxidants on intestinal histology, control and $\mathrm{H}_{2} \mathrm{O}_{2}$-treated tissues were removed from the Ussing chamber after $2 \mathrm{~h}$ of incubation, fixed, and stained as noted above.

Electrical and electrolyte flux measurements. The tissues were mounted in Ussing chambers and the measured transmural PD was continuously short-circuited to zero with the aid of an automatic voltage clamp (DVC-1000 voltage/current clamp; World Precision Instruments, Inc., New Haven, CT) using $\mathrm{Ag}-\mathrm{AgCl}$ electrodes connected to the bathing solution via agar bridges. After a 30-45-min pre-equilibration period, by which time the PD had stabilized, the tissues were stimulated from the serosal side by addition of various agonists. When inhibitors or stimulants were studied, those agents were added to the serosal bathing solution for at least $20 \mathrm{~min}$ before addition of the agonists. Conductances (G) were calculated from the open-circuit PD and the short circuit current (Isc) using Ohm's law. The maxima increase in Isc ( $\Delta \mathrm{Isc})$ above baseline values after the stimulation was calculated as previously described (5).

Unidirectional electrolyte fluxes of ${ }^{22} \mathrm{Na}$ and ${ }^{36} \mathrm{Cl}$ were measured as previously described in paired tissues that had electrical conductances differing by no more than $25 \%$ (5). The difference between mucosalto-serosal $\left(J_{\mathrm{ms}}\right)$ and serosal-to-mucosal $\left(\mathrm{J}_{\mathrm{sm}}\right)$ flux represented net transport $\left(J_{\text {net }}\right)$ with positive values indicating absorption and negative values representing secretion. The residual flux, $\mathrm{J}_{\text {net }}^{\mathrm{R}}$, which probably represents net $\mathrm{HCO}_{3}$ secretion or $\mathrm{K}$ absorption, was calculated by the formula $J_{\text {net }}^{R}=I s c-\left(J_{\text {net }}^{\mathrm{Na}}-J_{\text {net }}^{\mathrm{C}}\right)$.

Prostaglandin assays. The prostaglandin content of incubation solutions was determined by direct immunoassay on $100-300-\mathrm{ml} \mathrm{sam-}$ ples according to the method of Granstrom and Kindahl (9). The PG antisera had minimal cross-reactivity ( $<1 \%$ for most other prostaglandins), except for $6 \%$ cross-reactivity of the $E_{2}$ antisera with $P G A_{2}$ and 2-8\% cross-reactivity of the 6-keto-PGF ${ }_{1 \alpha}$ antisera for $\mathrm{PGF}_{1 \alpha}$ and $\mathrm{PGF}_{2 \alpha}$. The accuracy and precision of the assays were determined under each experimental condition as previously described $(5,10)$ and the validity of the assays was checked by high performance liquid chromatography. Prostaglandin production was calculated from the concentrations measured at successive 15-min time periods and ex- pressed as nanograms per 30 minutes per square centimeter. The values reported are $P G$ production in the first $30 \mathrm{~min}$.

$L D H$ measurements. The release of $\mathrm{LDH}$ from the intestinal epithelial cell was measured in aliquots of mucosal bathing solution before, and $1,5,15,30$, and $45 \mathrm{~min}$ after the serosal addition of $1 \mathrm{mM}$ $\mathrm{H}_{2} \mathrm{O}_{2}$ or the mucosal addition of $5 \mathrm{mM}$ sodium deoxycholate as a positive control. $\mathrm{LDH}$ was measured by a modification of the method of Wroblewski and LaDue (11). $\mathrm{H}_{2} \mathrm{O}_{2}$ at 1-mM concentrations was demonstrated to have no effect on LDH activity of standards, although $1 \mathrm{M} \mathrm{H}_{2} \mathrm{O}_{2}$ completed inhibited LDH activity.

$\mathrm{H}_{2} \mathrm{O}_{2}$ and $\mathrm{O}_{\overline{2}}$ measurements. The concentration of $\mathrm{H}_{2} \mathrm{O}_{2}$ in the mucosal or serosal bathing solutions was determined by a modification of the methods of Matalon et al. (12). 125- $\mu$ l aliquots of bathing solution were added to $500 \mu \mathrm{l}$ of $100-\mathrm{mM} \mathrm{KPO}_{4}(\mathrm{pH} 4.0)$ containing 20 purpurogallin units/ml of horseradish peroxidase, $1.5 \mathrm{mM}$ 4-aminoantipyrine, and $11 \mathrm{mM}$ phenol. The absorption was read at $510 \mathrm{~nm}$ and the concentration of $\mathrm{H}_{2} \mathrm{O}_{2}$ calculated from a standard curve.

The concentration of $\mathrm{O}_{\overline{2}}^{-}$generated by the $\mathrm{X} / \mathrm{XO}$ reaction was measured in the Ussing chamber with or without rat colonic tissue present, and with or without the pressure of SOD or diethyldithiocarbamate (DDTC), by a modification of the ferricytochrome reduction method as described by Pick and Mizel (13). Ferricytochrome was added directly to the serosal solution of the Ussing chamber to a final concentration of $160 \mu \mathrm{M}$, and $600-\mu \mathrm{l}$ aliquots of the serosal solution were taken before and at various time intervals after initiating the $\mathrm{X} / \mathrm{XO}$ reaction. The aliquots were added directly to the spectrophotometer cuvette and the reduction of ferricytochrome $c$ was determined using an $\epsilon \mathrm{m}$ of $21 \times 10^{3} \mathrm{M}^{-1} \cdot \mathrm{cm}^{-1}$.

Materials. Radioimmunoassay reagents for $\mathrm{PGE}_{2}$ and 6-keto$\mathrm{PGF}_{1 \alpha}$ analysis were obtained from Advanced Magnetics, Inc. (Cambridge, MA). X, XO, glucose oxidase (GO), SOD, horseradish peroxidase (type II, 200 purpurogallin units/mg), phenol ACS reagent, oxypurinol, ferricytochrome $c$ (type III), DDTC, CAT, thiourea (TH), tetrodotoxin (TTX), hexamethonium bromide (HEX), atropine sulfate (ATR), indomethacin (INDO), piroxicam (PXM), $\mathrm{PGE}_{2}, \mathrm{H}_{2} \mathrm{O}_{2}$, and sodium deoxycholate were all obtained from Sigma Chemical Co. (St. Louis, MO). Additional lots of XO, SOD, and CAT were obtained from Boehringer Mannheim Biochemicals (Indianapolis, IN) to confirm results obtained with Sigma enzymes. Deferoxamine mesylate (DES) was obtained from Ciba Pharmaceutical Co. (Summit, NJ). ${ }^{22} \mathrm{Na}$ and ${ }^{36} \mathrm{Cl}$ were purchased from Amersham Corp. (Arlington Heights, IL) and ICN Radiochemicals (Irvine, CA), respectively. Iloprost was a gift from Berlex Laboratories, Inc. (Cedar Knolls, NJ).

INDO and PXM were dissolved as stock solutions in DMSO such that only $10 \mu \mathrm{l}$ was added to $10 \mathrm{ml}$ of Ussing chamber solution, a concentration that has no effect on electrolyte transport. The other reagents were dissolved in Ringer solution. ROMs were created in the Ussing chamber either by adding varying concentrations of $\mathrm{XO}$ to the serosal Ringer solution containing $0.7 \mathrm{mM} \mathrm{X}$ or by the addition of $\mathrm{GO}$ to the glucose-Ringer solution containing $10 \mathrm{mM} \mathrm{G}$.

Statistical evaluation. If one of the four tissues in a set proved unsatisfactory for technical reasons, the entire group of data in that experiment was disregarded. Although $\sim 10 \%$ of the experiments performed were thus unusable, this design did allow the data to be normalized and presented as "percent of control response," which simplified its presentation and statistical analysis. The statistical significance of paired experiments was determined with the paired $t$ test. When multiple comparisons were undertaken, a parametric or nonparametric analysis of variance was used.

\section{Results}

Experimental design to determine the biologically active ROM. Fig. 1 depicts the experimental framework for determining which ROM was responsible for the $\Delta I s c$ created by the $\mathrm{X} / \mathrm{XO}$ reaction. The relative proportions of $\mathrm{O}_{\overline{2}}^{\overline{2}}$ and $\mathrm{H}_{2} \mathrm{O}_{2}$ created by the $\mathrm{X} / \mathrm{XO}$ reaction are dependent on the $\mathrm{pH}, \mathrm{PO}_{2}$, 


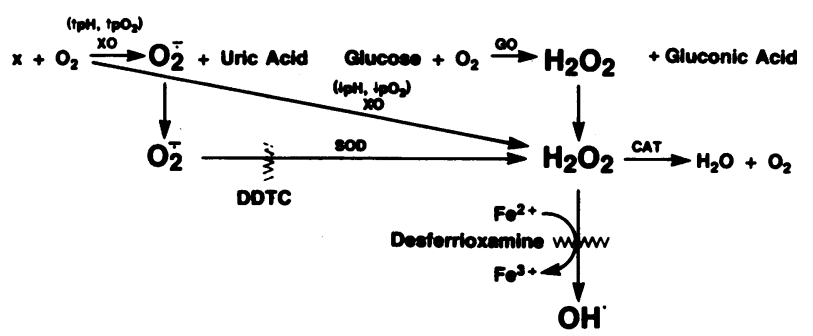

Figure 1. Experimental framework for determining which reactive oxygen metabolite is responsible for $\mathrm{X} / \mathrm{XO}$-mediated changes in intestinal electrolyte transport.

and $\mathrm{X}$ concentrations present; a higher $\mathrm{pH}$ and $\mathrm{PO}_{2}$ favor the production of $\mathrm{O}_{\dot{2}}^{-}$(14). As shown in Fig. 2, $A$ and $B$, the peak concentrations of $\mathrm{H}_{2} \mathrm{O}_{2}(129 \pm 24 \mu \mathrm{M})$ and $\mathrm{O}_{\dot{2}}^{-}(26 \pm 1 \mu \mathrm{M})$ represent a ratio of 5:1 in our system. The concentrations of $X$ and $\mathrm{XO}$ used were those determined previously by formal concentration-response experiments to give a maximal $\Delta \mathrm{Isc}$ (5). The Isc response to $\mathrm{X} / \mathrm{XO}$ was inhibited $90 \%$ by $25 \mu \mathrm{M}$ oxypurinol, provided that the $\mathrm{XO}$ was preincubated with oxypurinol at ambient $\mathrm{O}_{2}$ tension. If $\mathrm{O}_{\overline{2}}^{\overline{2}}$ was responsible for the $\Delta I s c$, then that response might be inhibited by the exogenous addition of SOD, which should hasten its metabolism to $\mathrm{H}_{2} \mathrm{O}_{2}$ (see Fig. 1). However, the exogenous addition of SOD might or might not have an effect on the $\Delta \mathrm{Isc}$, depending on whether endogenous SOD was limiting. Similarly, if $\mathrm{O}_{\dot{2}}^{-}$is the agonist, DDTC should theoretically enhance the response by slowing the conversion of $\mathrm{O}_{\overline{2}}^{\overline{2}}$ to $\mathrm{H}_{2} \mathrm{O}_{2}$. Conversely, if $\mathrm{H}_{2} \mathrm{O}_{2}$ was the biologically active ROM, the $\Delta$ Isc might be inhibited by DDTC, which should slow the conversion of $\mathrm{O}_{\overline{2}}^{\overline{2}}$ to $\mathrm{H}_{2} \mathrm{O}_{2}$.

As shown in Fig. 2, $A$ and $B$, while SOD did increase $\mathrm{H}_{2} \mathrm{O}_{2}$ production by an additional $45 \mu \mathrm{M}$, with a corresponding reduction in measurable $\mathrm{O}_{\overline{2}}$, DDTC actually inhibited the production of both $\mathrm{O}_{\overline{2}}^{\overline{2}}$ and $\mathrm{H}_{2} \mathrm{O}_{2}$. This unexpected effect of DDTC might be due to its ability to act as a reducing agent, or perhaps because it is capable of chelating the molybdate ion of $\mathrm{XO}$, thus inactivating the enzyme.

If $\mathrm{H}_{2} \mathrm{O}_{2}$ was the ROM responsible for the change in Isc, the $\Delta$ Isc would be diminished by the exogenous addition of CAT, which rapidly degrades $\mathrm{H}_{2} \mathrm{O}_{2}$ to $\mathrm{O}_{2}$ and $\mathrm{H}_{2} \mathrm{O}$ (Fig. 1). In addition, the $\Delta \mathrm{Isc}$ response would be mimicked by the exogenous addition of $\mathrm{H}_{2} \mathrm{O}_{2}$ or by use of a $\mathrm{H}_{2} \mathrm{O}_{2}$ generating system (G/GO) (Fig. $2 \mathrm{C}$ ).

To rule out the possibility that $\mathrm{OH}^{*}$ is the important ROM resulting in the $\Delta$ Isc, the tissues can be preincubated with the iron chelator DES, which will prevent the Haber-Weiss reaction. Furthermore, the effect of scavengers of $\mathrm{OH}^{\circ}$, such as thiourea, can be assessed. If $\mathrm{Fe}$ chelation or thiourea alters the $\Delta$ Isc to either $\mathrm{X} / \mathrm{XO}, \mathrm{G} / \mathrm{GO}$, or $\mathrm{H}_{2} \mathrm{O}_{2}$, this would be evidence that $\mathrm{OH}^{\circ}$ was the responsible species.

$R O M$ responsible for the $\Delta I s c$ of rat colon. Fig. 3 depicts the effect of SOD on the $\triangle \mathrm{Isc}$ response to ROMs created by the $\mathrm{X} / \mathrm{XO}$ reaction in the serosal bathing solution of rat colon mounted in the Ussing chamber. The response of the tissue to exogenous $\mathrm{X} / \mathrm{XO}$ is a biphasic, sustained increase in Isc, with peak 1 occurring at 3-6 min and peak 2 being maximal at $\sim 30 \mathrm{~min}$. Preincubation with increasing amounts of SOD had no effect on the peak 1 response to X/XO, but diminished peak 2 in a concentration-dependent manner. At $60-120 \mu \mathrm{M}$ SOD significantly $(P<0.001)$ inhibited the second peak in the

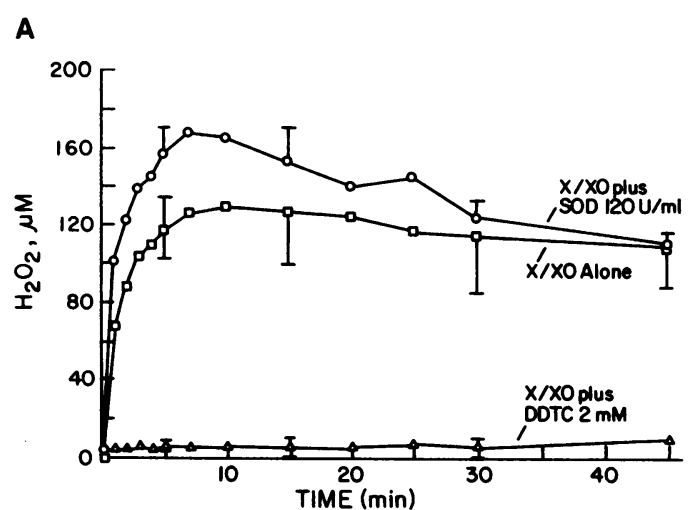

B

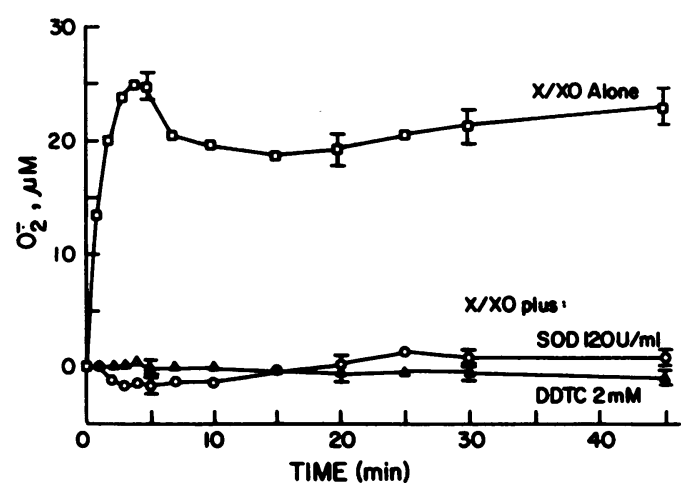

C

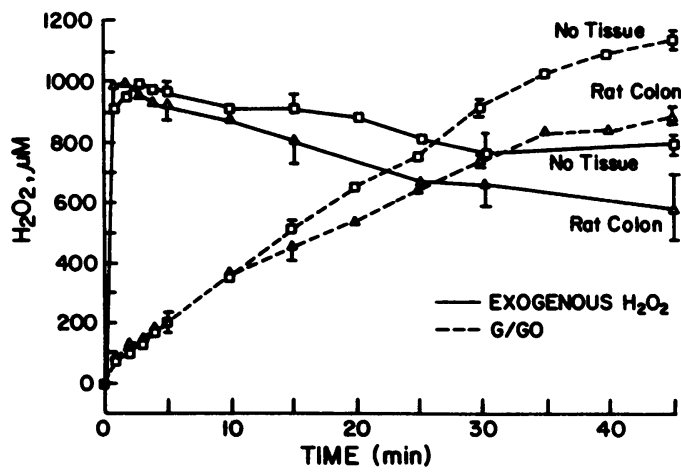

Figure 2. $A$, The effect of SOD $(120 \mathrm{U} / \mathrm{ml})$ and DDTC $(2 \mathrm{mM})$ on $\mathrm{H}_{2} \mathrm{O}_{2}$ production in the Ussing chamber created by the $\mathrm{X}(0.7 \mathrm{mM}) /$ $\mathrm{XO}(20 \mathrm{mU} / \mathrm{ml})$ reaction. $B$, The effect of SOD and DDTC on $\mathrm{O}_{\overline{2}}$ production created by the $\mathrm{X} / \mathrm{XO}$ reaction. $C$, Colonic metabolism of exogenously added $\mathrm{H}_{2} \mathrm{O}_{2}(1 \mathrm{mM})$ or $\mathrm{H}_{2} \mathrm{O}_{2}$ generated by the $\mathrm{G}(10$ $\mathrm{mM}) / \mathrm{GO}(200 \mathrm{mU} / \mathrm{ml})$ reaction in the Ussing chamber $(n=4$ for each experiment). This concentration of GO was shown by formal concentration-response experiments to give a maximal Isc response in the presence of $10 \mathrm{mM} \mathrm{G}$.

group of experiments in Fig. 3, but did not in subsequent experiments with different lots of SOD. This suggests presence of a contaminant in the Sigma enzymes. The stimulatory responses to $\mathrm{X} / \mathrm{XO}$ was essentially duplicated with enzymes purchased from Boehringer Mannhein Biochemicals, but there was no inhibition with SOD from this source.

Little information can be gained from the use of SOD and DDTC alone because endogenous stores of SOD might be 


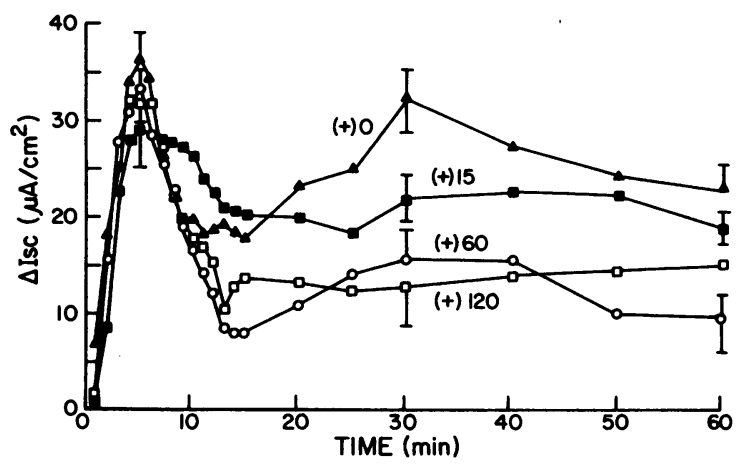

Figure 3. The effect of increasing concentrations of SOD on the $\triangle \mathrm{Isc}$ to ROMs created by the $X(0.7 \mathrm{mM}) / \mathrm{XO}(20 \mathrm{mU} / \mathrm{ml})$ reaction. SOD concentrations present in the serosal bathing solution were (in $\mathrm{U} / \mathrm{ml}): 0(\triangle), 15(\square), 60(0)$, and $120(\square)(n=5)$. The basal Isc ranged from 26 to $31 \mu \mathrm{A} / \mathrm{cm}^{2}$ before initiating the $X / X O$ reaction. The inhibition of the Isc at $30 \mathrm{~min}$ (peak 2) with higher concentrations of SOD was not reproduced when a different lot of SOD was used.

sufficient to maximally catalyze the formation of $\mathrm{H}_{2} \mathrm{O}_{2}$. Furthermore, the DDTC experiments were not easily interpretable because DDTC abolished the formation of both $\mathrm{O}_{\dot{2}}^{-}$and $\mathrm{H}_{2} \mathrm{O}_{2}$ (Fig. $2 \mathrm{~B}$ ). Both peaks 1 and 2 were diminished by preincubation with DDTC in a concentration-dependent manner and $2 \mathrm{mM}$ was sufficient to essentially abolish the $\Delta \mathrm{Isc}$ response to $\mathrm{X} / \mathrm{XO}$ (not shown). This was a specific response relating to DDTC's effect on metabolism of $\mathrm{O}_{2}$, rather than some nonspecific effect of DDTC on electrogenic $\mathrm{Cl}$ secretion by the colonocyte, because $\mathrm{PGE}_{2}\left(10^{-6} \mathrm{M}\right)$ had the same effect on $\Delta I s c$ in control tissues $\left(76 \pm 20 \mu \mathrm{A} / \mathrm{cm}^{2}\right)$ as it did in tissues preincubated with $2 \mathrm{mM}$ DDTC $\left(84 \pm 15 \mu \mathrm{A} / \mathrm{cm}^{2}\right)$.

The addition of CAT inhibited the $\Delta \mathrm{Isc}$ (Fig. 4) and 1,000 $\mathrm{U} / \mathrm{ml}$ essentially abolished the response. This suggests that $\mathrm{H}_{2} \mathrm{O}_{2}$ was the species responsible for the $\Delta \mathrm{Isc}$ to X/XO. Fig. 5 indicates that the creation of ROMs by the G/GO reaction or the exogenous addition of $\mathrm{H}_{2} \mathrm{O}_{2}$ mimicked the $\mathrm{X} / \mathrm{XO}$ response, although the time courses and magnitudes of peak 2 are somewhat different for the three ROM-generating systems.

The experiments described above do not rule out the possibility that the change in Isc is due to $\mathrm{OH}^{\circ}$. Preincubation of the

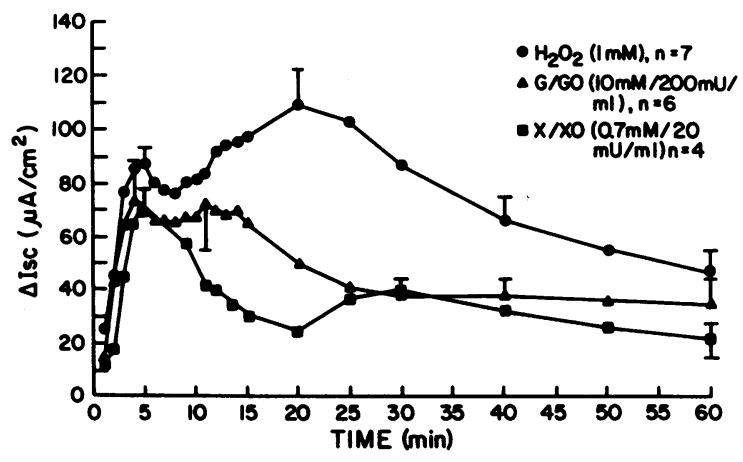

Figure 5. Comparison of the $\triangle \mathrm{Isc}$ response in rat colon to three ROM-generating systems: $\mathrm{H}_{2} \mathrm{O}_{2}, \mathrm{G} / \mathrm{GO}$, and $\mathrm{X} / \mathrm{XO}$. The curves shown for the different agonists represent maximal effective concentrations as determined by formal concentration-response studies. Note that while peak 1 is similar for all three systems, peak 2 varies in time and magnitude. The mean basal Isc concentrations were similar in each experiment before the addition or generation of $\mathrm{H}_{2} \mathrm{O}_{2}$.

tissue with DES had no effect on the $\triangle I s c$ to G/GO, nor did preincubation with the $\mathrm{OH}^{\circ}$ scavenger thiourea (Fig. 6). Fig. 6 also summarizes the experiments noted above, indicating the effects of the various agents on either the early (peak 1) or late (peak 2) Isc response. The data are consistent with the idea that $\mathrm{H}_{2} \mathrm{O}_{2}$ and not $\mathrm{OH}^{\circ}$ is the responsible ROM.

Mechanism of $\mathrm{H}_{2} \mathrm{O}_{2}$ effect on colonic electrolyte transport. $\mathrm{H}_{2} \mathrm{O}_{2}$ added to the mucosal bathing solution of the rat colon in the Ussing chamber stimulated the initial $\Delta$ Isc with a time course similar to serosally added $\mathrm{H}_{2} \mathrm{O}_{2}$, but the response was less and there was no second $\Delta \mathrm{Isc}$ peak response. Fig. 7 shows the concentration-response curve to serosal $\mathrm{H}_{2} \mathrm{O}_{2}$ with a maximal early and late peak response at $1 \mathrm{mM} \mathrm{H}_{2} \mathrm{O}_{2}$. There was inhibition of the response at concentrations $>1 \mathrm{mM}$. This diminished response at higher $\mathrm{H}_{2} \mathrm{O}_{2}$ concentrations was a toxic effect, as confirmed by histological study (Fig. 8). Only minor histological differences could be discerned between control tissues and those exposed to $1 \mathrm{mM} \mathrm{H}_{2} \mathrm{O}_{2}$ (Fig. 8 B). Furthermore, $1 \mathrm{mM}$ serosal $\mathrm{H}_{2} \mathrm{O}_{2}$ addition did not increase the release of LDH into the mucosal bathing solution (at $15 \mathrm{~min}$, control, $227 \pm 49 \mathrm{IU} /$ liter, vs. serosal $\mathrm{H}_{2} \mathrm{O}_{2}, 209 \pm 33 \mathrm{IU} /$ liter, $n=4$ ),

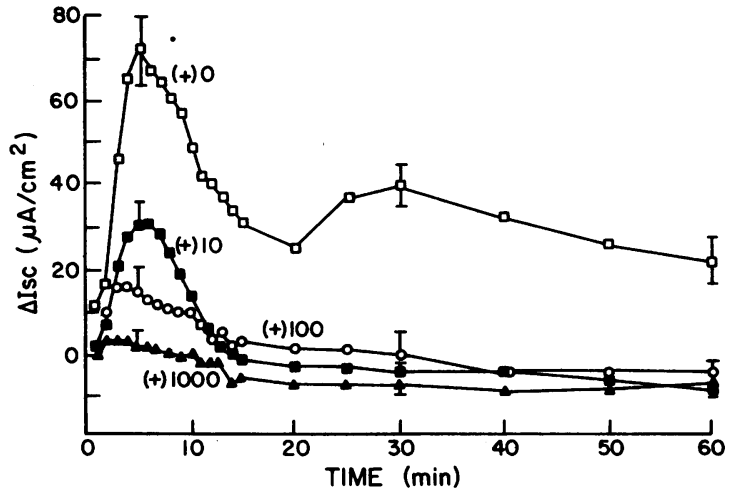

Figure 4. Effect of CAT on $\triangle \mathrm{Isc}$ response to $\mathrm{X} / \mathrm{XO}$. CAT present in the serosal bathing solution before stimulation with $\mathrm{X} / \mathrm{XO}$ were (in $\mathrm{U} / \mathrm{ml}): 0(\square), 10(\square), 100(0)$, and $1,000(\Delta)(n=4)$. The basal Isc ranged from 27 to $35 \mu \mathrm{A} / \mathrm{cm}^{2}$ before initiating the $\mathrm{X} / \mathrm{XO}$ reaction.

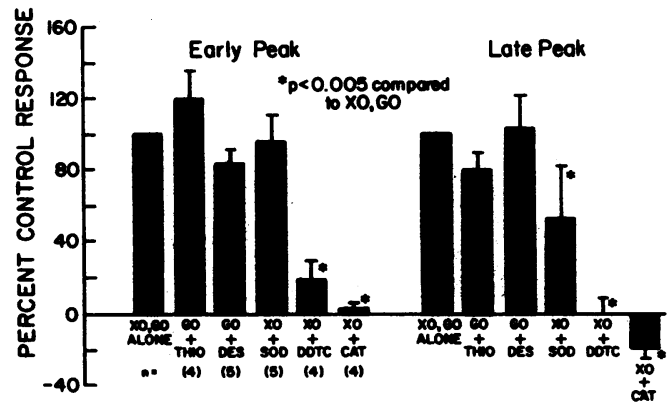

Figure 6. Summary of the effect of various inhibitors or stimulants of oxygen metabolism on the early and late peak $\Delta I s c$ response to ROMs created by either the $\mathrm{X} / \mathrm{XO}$ or the $\mathrm{G} / \mathrm{GO}$ reaction. The responses in each study are normalized to the percent of control response. 


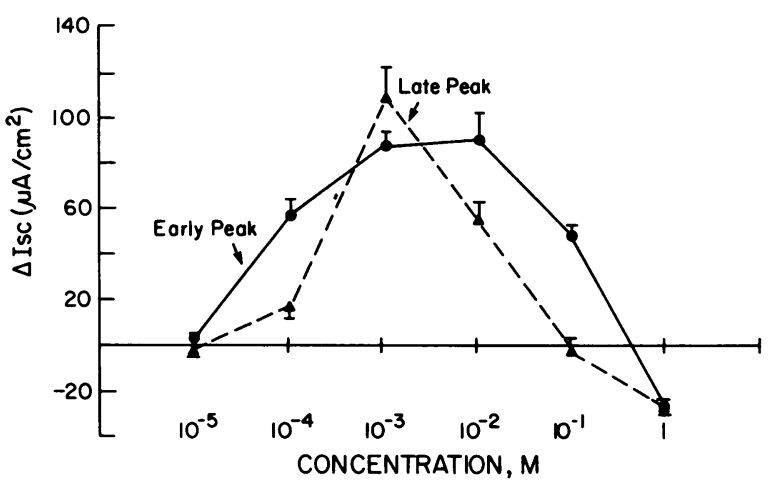

Figure 7. Concentration-response curve for the $\Delta \mathrm{Isc}$ response of rat colon to $\mathrm{H}_{2} \mathrm{O}_{2}$ added to the serosal bathing solution. Concentrations $>1 \mathrm{mM}$ diminish the $\Delta \mathrm{Isc}$ as a result of a toxic effect of the oxidant (see Fig. 8).

whereas $5 \mathrm{mM}$ mucosal deoxycholate significantly $(P<0.05, n$ $=4$ ) increased mucosal bathing solution LDH to $403 \pm 36 \mathrm{IU} /$ liter. In contrast, exposure of rat colon for $1 \mathrm{~h}$ to $1 \mathrm{M}$ serosal $\mathrm{H}_{2} \mathrm{O}_{2}$ completely destroyed the crypt epithelium (Fig. $8 \mathrm{C}$ ).

The effect of $1 \mathrm{mM}$ serosal $\mathrm{H}_{2} \mathrm{O}_{2}$ on rat colonic electrolyte transport is shown in Table $\mathrm{I}$, section $A . \mathrm{H}_{2} \mathrm{O}_{2}$ diminished mucosal-to-serosal fluxes of $\mathrm{Na}$ and $\mathrm{Cl}$, stimulated serosal-tomucosal fluxes of $\mathrm{Cl}$, and significantly increased the Isc and PD. As a result of these changes in unidirectional fluxes, there was a significant inhibition of $\mathrm{J}_{\mathrm{Na}}^{\text {net }}$ and a reversal of $\mathrm{J}_{\mathrm{Cl}}^{\text {net }}$ from absorption to secretion. These changes indicate that $\mathrm{H}_{2} \mathrm{O}_{2}$ was inhibiting neutral $\mathrm{NaCl}$ absorption and stimulating electrogenic $\mathrm{Cl}$ secretion in rat colon. This concentration of $\mathrm{H}_{2} \mathrm{O}_{2}$ had no effect on transepithelial electrical conductance (G).

In our previous study with $\mathrm{X} / \mathrm{XO}(5)$, the $\Delta$ Isc response was inhibited by cyclooxygenase inhibitors as well as by inhibitors of ENS activity. Accordingly, we determined the effect of the cyclooxygenase inhibitors INDO and PXM on the early and late peak $\Delta$ Isc response to $\mathrm{H}_{2} \mathrm{O}_{2}$, and contrasted these with the effects of the ENS inhibitors TTX, HEX, and high-dose ATR (Fig. 9). These inhibitors all reduced the peak $1 \Delta$ Isc by $\sim 70 \%$. INDO $\left(10^{-6} \mathrm{M}\right)$, but not PXM $\left(10^{-6} \mathrm{M}\right)$, inhibited the peak 2 response. Because PXM has a chemical structure that should be sensitive to oxidants, we repeated the experiments but preincubated with increasing concentrations of PXM. A concentration-response inhibition of both the early and late peak responses could be demonstrated, and at $10^{-4} \mathrm{M}$ PXM both the early and late peaks were inhibited by $\sim 70 \%(P$ $<0.01)$. This suggests that the lack of inhibition of the late peak with lower concentrations of PXM was due to the timedependent destruction of the drug by the oxidant effect of $\mathrm{H}_{2} \mathrm{O}_{2}$. Table I, section $B$, shows the effect of INDO on the electrolyte transport response to $\mathrm{H}_{2} \mathrm{O}_{2}$. The inhibition of neutral $\mathrm{NaCl}$ absorption and the stimulation of electrogenic $\mathrm{Cl}$ secretion were diminished, but not abolished, by cyclooxygenase blockade.

The experiments shown in Fig. 9 suggest that either the ENS is releasing prostaglandins that alter electrolyte transport or, alternatively, that prostaglandins release neurotransmitters from the ENS and the neurotransmitters are the major agonists involved in the Isc response to $\mathrm{H}_{2} \mathrm{O}_{2}$. To determine which of these is more likely, we measured $\mathrm{PGE}_{2}$ and $\mathrm{PGI}_{2}$ (assayed as 6-keto- $\mathrm{PGF}_{1 \alpha}$ ) production in the experiments depicted in Fig. 9. As shown in Table II, $\mathrm{H}_{2} \mathrm{O}_{2}$ increased production of $\mathrm{PGE}_{2} \sim$ 7-8-fold and 6-keto-PGF $1 \alpha$ production 15-18-fold. The peak output by $\mathrm{PGE}_{2}$ was in the first 15 -min period after the addition of $\mathrm{H}_{2} \mathrm{O}_{2}$, a time course compatible with the stimulation of Isc. This stimulation of prostaglandin production was inhibited by pretreatment with INDO or PXM, but not by preincubation with the neural inhibitors TTX, HEX, and ATR. These results suggest that the prostaglandins produced by the ROMs were initiating $\mathrm{Cl}$ secretion in large part by activating the ENS.

To determine if $\mathrm{PGE}_{2}$ or $\mathrm{PGI}_{2}$ was a more important stimulant of the ENS, the Isc response to serosal $\mathrm{PGE}_{2}$ was compared with that of the Iloprost, a stable analogue of $\mathrm{PGI}_{2}$, in the presence and absence of TTX. In rat colon preincubated with $10^{-6} \mathrm{M}$ INDO to inhibit endogenous PG production (Table III), the $\Delta \mathrm{Isc}$ to $\mathrm{PGE}_{2}$ was not diminished by neural blockade with TTX, whereas the $\Delta$ Isc to Iloprost was inhibited 94\%. These data suggest that while $\mathrm{PGE}_{2}$ has its stimulatory
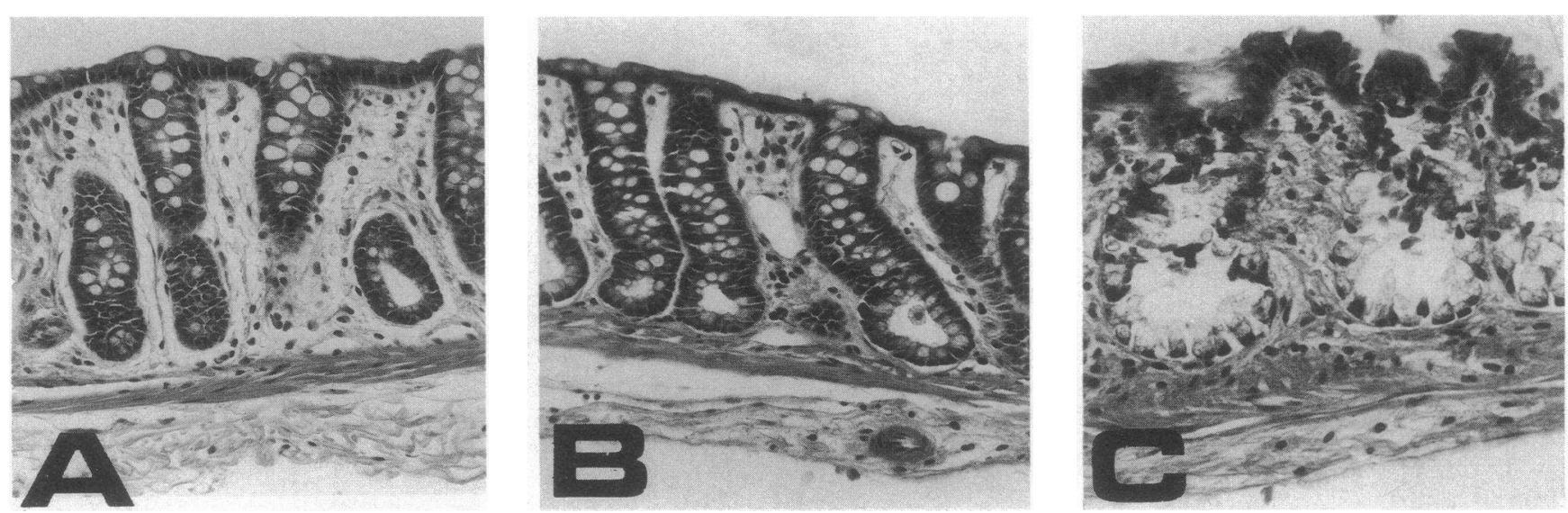

Figure 8. Histology of rat colon after incubation for $1 \mathrm{~h}$ in the Ussing chamber. $A$, control; $B, 1 \mathrm{mM} \mathrm{H} \mathrm{H}_{2} \mathrm{O}_{2} ; C, 1 \mathrm{M} \mathrm{H}_{2} \mathrm{O}_{2}$. Note that the submucosa, with its component of the ENS, is present in this preparation of stripped rat colon. There are only minor changes in the histology of tissues as the result of incubation with $1 \mathrm{mM} \mathrm{H}_{2} \mathrm{O}_{2}$ : slight dilatation of crypts and more cuboidal appearance of the surface colonocytes $(B)$ as compared with control tissues $(A)$. In contrast, after incubation with $1 \mathrm{M} \mathrm{H}_{2} \mathrm{O}_{2}(C)$, the crypt epithelium is completely destroyed. 
Table I. Effect of $1.0 \mathrm{mM}$ Hydrogen Peroxide on Rat Colonic Electrolyte Transport (A) and Response to $10^{-6} \mathrm{M}$ Indomethacin $(B)(n=8)$

\begin{tabular}{|c|c|c|c|c|c|c|c|c|c|c|}
\hline & $\mathrm{J}_{\mathbf{m}}^{\mathrm{Na}}$ & $J_{\mathbf{m}}^{\mathrm{Na}}$ & $J_{\mathrm{net}}^{\mathrm{Na}}$ & $\mathrm{J}_{\mathrm{ms}}^{\mathrm{d}}$ & $\mathbf{J}_{\mathrm{sm}}^{\mathrm{G}}$ & $J_{\text {net }}^{\mathrm{C}}$ & Isc & $\mathbf{J}_{\mathrm{net}}^{\mathbf{R}}$ & PD & G \\
\hline & \multicolumn{8}{|c|}{$\mu e q / h$ per $\mathrm{cm}^{2}$} & $m V$ & $\mathrm{mS} / \mathrm{cm}^{2}$ \\
\hline \multicolumn{11}{|l|}{ A. } \\
\hline (1) Basal & $15.3 \pm 1.4$ & $10.5 \pm 0.8$ & $4.8 \pm 0.9$ & $19.8 \pm 1.2$ & $15.9 \pm 1.0$ & $3.9 \pm 1.0$ & $1.3 \pm 0.1$ & $0.4 \pm 0.7$ & $-1.8 \pm 0.3$ & $20.1 \pm 1.7$ \\
\hline (2) $\mathrm{H}_{2} \mathrm{O}_{2}$ & $13.5 \pm 1.0$ & $11.2 \pm 1.3$ & $2.2 \pm 0.5$ & $16.8 \pm 1.0$ & $17.3 \pm 1.4$ & $-0.6 \pm 1.0$ & $3.1 \pm 0.3$ & $0.3 \pm 0.8$ & $-4.1 \pm 0.7$ & $21.7 \pm 2.0$ \\
\hline (2 vs. 1$)$ & $P<0.01$ & NS & 0.01 & 0.001 & 0.05 & 0.001 & 0.001 & NS & 0.001 & NS \\
\hline \multicolumn{11}{|l|}{ B. } \\
\hline (3) INDO & $17.3 \pm 1.1$ & $10.6 \pm 0.7$ & $6.7 \pm 0.8$ & $21.9 \pm 1.2$ & $15.3 \pm 0.9$ & $6.6 \pm 1.1$ & $0.5 \pm 0.1$ & $0.5 \pm 1.3$ & $-0.8 \pm 0.2$ & $19.4 \pm 1.9$ \\
\hline (4) INDO $+\mathrm{H}_{2} \mathrm{O}_{2}$ & $15.4 \pm 1.3$ & $10.3 \pm 0.8$ & $5.1 \pm 0.9$ & $19.4 \pm 0.9$ & $15.6 \pm 0.9$ & $3.8 \pm 1.0$ & $1.6 \pm 0.3$ & $0.3 \pm 0.8$ & $-2.3 \pm 0.3$ & $20.0 \pm 2.4$ \\
\hline (4 vs. 3 ) & $P<0.01$ & NS & 0.01 & 0.05 & NS & 0.01 & 0.001 & NS & 0.001 & NS \\
\hline (3 vs. 1 ) & $P<\mathrm{NS}$ & NS & NS & NS & NS & 0.05 & 0.001 & NS & 0.001 & NS \\
\hline (4 vs. 2 ) & $P<\mathrm{NS}$ & NS & 0.01 & 0.05 & NS & 0.01 & 0.01 & NS & 0.01 & NS \\
\hline
\end{tabular}

Four tissues from each animal were studied simultaneously. Two pairs had INDO in the Ringer solution. After a basal measurement (mean of two 15-min flux periods) the agonist $\left(\mathrm{H}_{2} \mathrm{O}_{2}\right)$ was added to the serosal solution, and after a 15-min equilibration period fluxes were measured for two additional periods and meaned. 2 vs. $1=$ response to control colon to $\mathrm{H}_{2} \mathrm{O}_{2} ; 4$ vs. 3 = response of the INDO-treated colon to the $\mathrm{H}_{2} \mathrm{O}_{2} ; 3$ vs. 1 = response of the control colon to INDO; 4 vs. 2 = effect of INDO on the $\mathrm{H}_{2} \mathrm{O}_{2}$ response.

effect on electrogenic $\mathrm{Cl}$ secretion through colonocyte receptors, $\mathrm{PGI}_{2}$ stimulates $\mathrm{Cl}$ secretion via receptors on the ENS.

\section{Discussion}

The focus of oxygen radicals and oxidants in biology has been on ROMs as injurious agents (1-3). In the gastrointestinal tract a role for ROMs has been postulated in various forms of enteritis $(1,2,15)$ and gastric ulceration $(16,17)$. Ischemic injury has been the best studied model where ROMs created by an endogenous $\mathrm{X} / \mathrm{XO}$ reaction and from the respiratory burst of neutrophils seem to be responsible for reperfusion injury, especially through the creation of $\mathrm{OH}^{*}(18-21)$. Recent studies indicating that sulfasalazine and 5-aminosalicylic acid, two important drugs in the treatment of inflammatory bowel

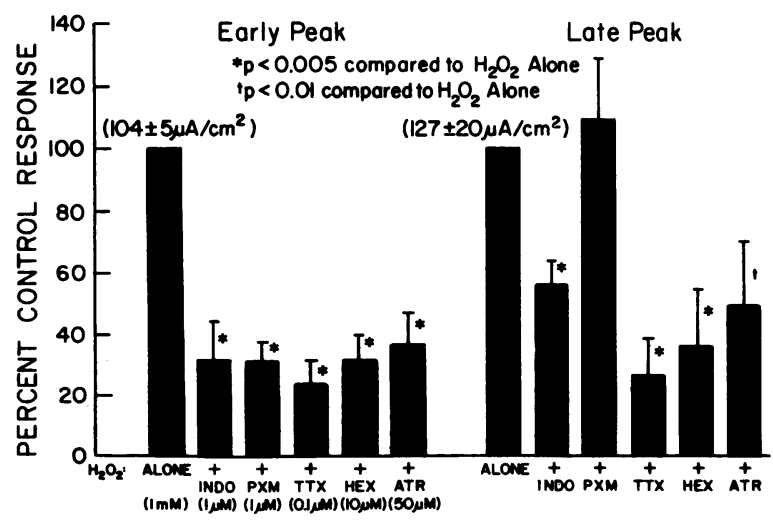

Figure 9. Summary of the effect of preincubation with cyclooxygenase inhibitors (INDO and PXM) and various neural inhibitors or antagonists (TTX, HEX, and ATR) on both the early and late peak Isc response to $1 \mathrm{mM} \mathrm{H}_{2} \mathrm{O}_{2}$. The data in each study are normalized to the percent of control response. When studied in higher concentrations, PXM was capable of inhibiting the late peak response as well. disease, are also reactive oxygen scavengers (22-24) have furthered the idea that ROMs play a fundamental role in gastrointestinal inflammation. The present investigation, however, suggests that ROMs might have a physiologic, protective effect in the intestine, if one considers intestinal secretion and the resulting diarrhea a protective event that might wash offending microorganisms or antigens from the intestinal tract. Prostaglandin release might also be protective to the intestinal mucosa.

Our previous studies using $\mathrm{X} / \mathrm{XO}$ demonstrated the ability of ROMs to stimulate electrogenic $\mathrm{Cl}$ secretion and inhibit neutral $\mathrm{NaCl}$ absorption (5). The experiments reported here indicate that $\mathrm{H}_{2} \mathrm{O}_{2}$ is the important $\mathrm{ROM}$ altering intestinal electrolyte transport. The inhibition of the $\Delta \mathrm{Isc}$ response to $\mathrm{X} / \mathrm{XO}$ by CAT, coupled with reproduction of the $\mathrm{X} / \mathrm{XO}$ response with $\mathrm{G} / \mathrm{GO}$ and exogenous $\mathrm{H}_{2} \mathrm{O}_{2}$, provide strong evidence that $\mathrm{H}_{2} \mathrm{O}_{2}$ is the active species altering transport. The possibility that $\mathrm{OH}^{\circ}$, formed from $\mathrm{H}_{2} \mathrm{O}_{2}$ by the Haber-Weiss

Table II. Prostaglandin $E_{2}$ and Prostacyclin (Measured as 6-keto-PGF $F_{I \alpha}$ ) Production by Rat Colon in Response to Hydrogen Peroxide $\left(10^{-3} \mathrm{M}\right)$ and Effect of Cyclooxygenase and Neural Inhibitors $(n=5)$

\begin{tabular}{llc}
\hline \multicolumn{1}{c}{ Agonist + inhibitors } & $\mathrm{PGE}_{2}$ & 6-keto-PGF \\
& \multicolumn{2}{c}{$n g / 30$ min per cm } \\
& $1.2 \pm 0.3$ & $4.1 \pm 0.9$ \\
Control & $8.0 \pm 1.5^{*}$ & $73.6 \pm 6.4^{*}$ \\
$\mathrm{H}_{2} \mathrm{O}_{2}$ alone & $8.3 \pm 1.3^{*}$ & $62.0 \pm 4.5^{*}$ \\
$+\mathrm{TTX}\left(10^{-7} \mathrm{M}\right)$ & $9.0 \pm 0.7^{*}$ & $75.7 \pm 12.1^{*}$ \\
$+\mathrm{HEX}\left(10^{-5} \mathrm{M}\right)$ & $9.6 \pm 2.5^{*}$ & $75.1 \pm 15.5^{*}$ \\
$+\mathrm{ATR}\left(5 \times 10^{-5} \mathrm{M}\right)$ & $1.9 \pm 0.4^{\ddagger}$ & $17.5 \pm 2.9^{\ddagger}$ \\
$+\mathrm{INDO}\left(10^{-6} \mathrm{M}\right)$ & $1.7 \pm 0.8^{\ddagger}$ & $33.8 \pm 7.2^{\ddagger}$ \\
$+\mathrm{PXM}\left(10^{-6} \mathrm{M}\right)$ & &
\end{tabular}

${ }^{*} P<0.005$ control vs. agonist or agonist + inhibitor; ${ }^{\ddagger} P<0.005 \mathrm{ag}-$ onist vs. agonist + inhibitor. 
Table III. Effect of $10^{-7} M T T X$ on the $\triangle I$ sc to Maximally Effective Concentrations of $P G E_{2}$ or the $\mathrm{PGI}_{2}$ Analogue, Iloprost $(n=6)$

\begin{tabular}{lcc}
\hline Stimulus/inhibitor (concentration) & At $5 \mathrm{~min}$ & At $30 \mathrm{~min}$ \\
\hline & & $\mu \mathrm{A} / \mathrm{cm}^{2}$ \\
$\mathrm{PGE}_{2}\left(2.8 \times 10^{-8} \mathrm{M}\right)$ & & \\
Alone & $59 \pm 14.6$ & $38 \pm 10.0$ \\
+TTX $\left(10^{-7} \mathrm{M}\right)$ & $52 \pm 11.7$ & $39 \pm 9.7$ \\
Iloprost $\left(2.8 \times 10^{-7} \mathrm{M}\right)$ & & \\
Alone & $72 \pm 17.2$ & $66 \pm 17.7$ \\
+TTX $\left(10^{-7} \mathrm{M}\right)$ & $4 \pm 1.0^{\ddagger}$ & $7 \pm 2.6^{\ddagger}$ \\
\hline
\end{tabular}

The concentrations of $\mathrm{PGE}_{2}$ and Iloprost uses were those giving maximal responses in formal concentration-response studies. In these experiments tissues were preincubated for $20 \mathrm{~min}$ with $10^{-6} \mathrm{M}$ indomethacin to inhibit endogenous prostaglandin production before stimulation with $\mathrm{PGE}_{2}$ or Iloprost.

$* P<0.002$.

reaction, was responsible for the changes in transport was effectively ruled out by the studies with DES and TH, agents that would prevent the formation of or decrease the concentration of $\mathrm{OH}^{*}$.

The inhibition of the $\mathrm{H}_{2} \mathrm{O}_{2}$ effect on electrolyte transport by indomethacin and piroxicam indicates the important role that cyclooxygenase products play in the electrolyte transport effect of oxidants. $\mathrm{H}_{2} \mathrm{O}_{2}$ was a potent stimulus of $\mathrm{PGE}_{2}$ and 6-keto-PGF 1 $_{\alpha}$ production. In fact, 6-keto-PGF 1 $_{1 \alpha}$ production by $\mathrm{H}_{2} \mathrm{O}_{2}$ was the highest of any agonist we have studied, including platelet activating factor, chemotactic peptide (FMLP), and anti-IgE (5). These results do not rule out the possibility that ROMs might also directly stimulate the enterocyte as suggested by Olson et al. (25) in cultured monolayers of T84 colon carcinoma cells.

There are several potential mechanisms whereby $\mathrm{H}_{2} \mathrm{O}_{2}$ might stimulate production of prostaglandins in the intestine. First, peroxides are important cofactors ("peroxide tone") for prostaglandin biosynthesis, as demonstrated by the exogenous addition of either $\mathrm{H}_{2} \mathrm{O}_{2}$ or lipid peroxides to tissues (26-28). However, there may be an important dose-response effect in that high levels of lipoperoxides, perhaps through $\mathrm{OH}^{\circ}$ formation, will inactivate prostaglandin and prostacyclin synthases (28). The ability of low concentrations of hydroperoxides to activate PGH synthase is not just a laboratory phenomenon; it can be shown that activation of phagocytic leukocytes will cause hydroperoxide release that is sufficient to stimulate prostaglandin production from cocultured lymphoma cells (29). These experiments suggest a second possible mechanism for peroxide stimulation of prostaglandin production: the activation of inflammatory or mesenchymal cells. $\mathrm{H}_{2} \mathrm{O}_{2}$, myeloperoxidase, and eosinophilic peroxidase will stimulate $\mathrm{PGE}_{2}$ and/ or $\mathrm{PGI}_{2}$ production in mast cells $(30-33)$, fibroblasts $(34,35)$, renal gomerular mesangial cells (36), and cultured endothelial cells $(37,38)$. The mechanism of this stimulation is unclear, but in the endothelial cells it seems to involve gating of $\mathrm{Ca}^{2+}$ across the cell membrane either as the result of a receptor-mediated event or secondary to lipid peroxidation of the cell membrane, making it more permeable to $\mathrm{Ca}^{2+}$ with subsequent liberation of AA from membrane stores (38).

Increased prostaglandins in the lamina propria of the intestine might initiate changes in enterocyte electrolyte transport by directly stimulating colonocyte adenylate cyclase or, as has recently been suggested by Goerg et al. (6) and Diener et al. (7), could activate receptors on the ENS with resulting release of secretory neurotransmitters. We have confirmed their studies that indicate $\mathrm{PGI}_{2}$ is an important potential neuromodulator in the rat colon. The effect of Iloprost, but not $\mathrm{PGE}_{2}$, on electrolyte transport was essentially abolished by pretreatment with TTX. Furthermore, the high concentrations of $\mathrm{PGI}_{2}$ produced by $\mathrm{H}_{2} \mathrm{O}_{2}$ and the inhibition of the $\mathrm{H}_{2} \mathrm{O}_{2}$ effect with TTX, HEX, and high-dose ATR all implicate $\mathrm{PGI}_{2}$ as an important intermediate in $\mathrm{H}_{2} \mathrm{O}_{2}$-stimulated $\mathrm{Cl}$ secretion in rat colon.

An issue for consideration is whether the prostaglandin synthesis and altered electrolyte transport we report here, artificially created in an in vitro system, might occur in vivo in either normal or inflamed intestine. Studies of isolated neutrophils clearly demonstrate that $10^{5}-10^{6}$ neutrophils can generate concentrations of $\mathrm{H}_{2} \mathrm{O}_{2}$ in the range of $10-100 \mu \mathrm{M} / \mathrm{ml}(4$, 39). This is certainly within the dose-response range for the changes in electrolyte transport demonstrated here. In the normal mammalian colon, phagocytes (eosinophils, neutrophils, and macrophages) are present in numbers approaching $10^{6}$ cells/g of tissue (40). In inflammatory diseases of intestine, the concentration of these cells would increase even more. In our studies $\mathrm{H}_{2} \mathrm{O}_{2}$ concentrations $<1 \mathrm{mM}$ caused very little damage to the intestinal mucosa; it would appear that the intestinal oxidase defense mechanisms are sufficient to handle this level of oxidant stress. At $1 \mathrm{mM} \mathrm{H}_{2} \mathrm{O}_{2}$ we could not detect release of $\mathrm{LDH}$ or changes in paracellular permeability, a finding similar to that reported by Welsh et al. in cultured MadinDarby Canine Kidney cells (41), and there was no effect on epithelial histology. At concentrations $>1 \mathrm{mM}$, we and others $(41,42)$ find irreversible permeability changes in the epithelium and, at still higher concentrations, severe damage to the epithelium (see Fig. 8).

In summary, this investigation demonstrates $\mathrm{H}_{2} \mathrm{O}_{2}$ to be a potent agonist for electrogenic $\mathrm{Cl}$ secretion and for inhibition of neutral $\mathrm{NaCl}$ absorption in the rat colon. This process is mediated by release of prostaglandins from the lamina propria. $\mathrm{PGI}_{2}$ is a prominent prostaglandin elaborated in response to $\mathrm{H}_{2} \mathrm{O}_{2}$ and it appears to have its major effect on electrolyte transport by activating the ENS. The specific neurotransmitters acting at the level of the colonocyte remain to be determined. Intestinal secretion that may result in diarrhea can be viewed as a protective mechanism in the intestine, as may the release of prostaglandin. Furthermore, recently it has been suggested that ROMs might be important stimulants of cell division in the damaged intestine, and thus might play an important initiating role in epithelial repair (43). Thus ROMs, though clearly damaging agents at high concentration, also appear to play protective and reparative roles in the intestine.

\section{Acknowledgments}

We wish to thank Mrs. Patricia Brown and Ms. Marie A. Jost for excellent secretarial assistance, Dr. Frederic Askin for photomicro- 
graphs of colonic tissue, and Dr. Myron Cohen and Dr. Irwin Fridovich for helpful discussion of oxygen radical and oxidant biochemistry.

The work was supported by grants DK- 15350 and DK-34987 from the National Institutes of Health.

\section{References}

1. Granger, D. N., L. A. Hernandez, and M. B. Grisham. 1986 Reactive oxygen metabolites: mediators of cell injury in the digestive system. Viewpoints on Digestive Diseases. 18:13-16.

2. Cross, C. E., B. Halliwell, E. T. Borish, W. A. Pryor, B. N. Ames, R. L. Saul, J. M. McCord, and D. Harman. 1987. Oxygen radicals and human disease. Ann. Intern. Med. 107:526-545.

3. Klebanoff, S. J. 1988. Phagocytic cells: products of oxygen metabolism. In Inflammation: Basic Principles and Clinical Correlates. J. I. Gallin, I. M. Goldstein, and R. Synderman, editors. Raven Press, Ltd., New York. 391-444.

4. Test, S. T., and S. J. Weiss. 1984. Quantitative and temporal characterization of the extracellular $\mathrm{H}_{2} \mathrm{O}_{2}$ pool generated by human neutrophils. J. Biol. Chem. 259:399-405.

5. Bern, M. J., C. W. Sturbaum, S. S. Karayalcin, H. M. Berschneider, J. T. Wachsman, and D. W. Powell. 1989. Immune system control of rat and rabbit colonic electrolyte transport: role of prostaglandins and enteric nervous system. J. Clin. Invest. 83:1810-1820.

6. Goerg, K. J., M. Roux, R. Wanitschke, and K. H. Meyer zum Buschenfelde. 1986. Die Bedeutung des Meissnerschen Plexus für die sekretorische Funktion der Colonschleimhaut. Z. Gastroenterol. 24:70-78.

7. Diener, M., R. J. Bridges, S. F. Knobloch, and W. Rummel. 1988. Neuronally mediated and direct effects of prostaglandins on ion transport in rat colon descendens. Naunyn-Schmiedeberg's Arch. Pharmacol. 337:74-78.

8. Binder, H. J., and C. L. Rawlins. 1973. Electrolyte transport across isolated large intestinal mucosa. Am. J. Physiol. 225:12321239.

9. Granstrom, E., and H. Kindahl. 1978. Radioimmunoassay of prostaglandins and thromboxanes. Adv. Prostaglandin Thromboxane Res. 5:119-210.

10. Lawson, L. D., and D. W. Powell. 1987. Bradykinin-stimulated eicosanoid synthesis and secretion by rabbit ileal components. Am.J. Physiol. 252 (Gastrointest. Liver Physiol. 15):G783-G790.

11. Wroblewski, F., and J. S. LaDue. 1955. Lactate dehydrogenase activity in blood. Proc. Soc. Exp. Biol. Med. 90:210-213.

12. Matalon, S., J. S. Beckman, M. E. Duffey, and B. A. Freeman. 1989. Oxidant inhibition of epithelial active sodium transport. Free Radical Biol. \& Med. 6:557-564.

13. Pick, E., and D. Mizel. 1981. Rapid microassays for the measurement of superoxide and hydrogen peroxide production by macrophages in culture using an automatic enzyme immunoassay. J. Immunol. Methods. 46:211-226.

14. Fridovich, I. 1970. Quantitative aspects of the production of superoxide anion radical by milk xanthine oxidase. J. Biol. Chem. 16:4053-4057.

15. Granger, D. N., M. B. Grisham, B. J. Zimmerman, and C. Von Ritter. 1988. Reactive oxygen metabolites as mediators of cell injury in the intestine. In Inflammatory Bowel Disease: Current Status and Future Approach. R. P. MacDermott, editor. Elsevier Science Publishers B. V., Amsterdam. 255-260.

16. Smith, S. M., L. Holm-Rutili, M. A. Perry, M. B. Grisham, K. E. Arfors, D. N. Granger, and P. R. Kvietys. 1987. Role of neutrophils in hemorrhagic shock-induced gastric mucosal injury in the rat. Gastroenterology. 93:466-471:

17. Olson, C. E. 1988. Glutathione modulates toxic oxygen metabolite injury of canine chief cell monolayers in primary culture. Am. J. Physiol. 254 (Gastrointest. Liver Physiol. 17):G49-G56.
18. Parks, D. A., G. B. Bulkley, D. N. Granger, S. R. Hamilton, and J. M. McCord. 1982. Ischemic injury in the cat small intestine: role of superoxide radicals. Gastroenterology. 82:9-15.

19. Grisham, M. B., L. A. Hernandez, and D. N. Granger. 1986. Xanthine oxidase and neutrophil infiltration in intestinal ischemia. Am. J. Physiol. 251 (Gastrointest. Liver Physiol. 14):G567-G574.

20. Hernandez, L. A., M. B. Grisham, B. Twohig, K. E. Arfors, J. M. Harlan, and D. N. Granger. 1987. Role of neutrophils in ischemia-reperfusion-induced microvascular injury. Am. J. Physiol. 253 (Heart Circ. Physiol. 22):H699-H703.

21. Hernandez, L. A., M. B. Grishman, and D. N. Granger. 1987. A role for iron in oxidant-mediated ischemic injury to intestinal microvasculature. Am. J. Physiol. 253 (Gastrointest. Liver Physiol. 16):G49-G53.

22. Miyachi, Y., A. Yoshioka, S. Imamura, and Y. Niwa. 1987. Effect of sulphasalazine and its metabolites on the generation of reactive oxygen species. Gut. 28:190-195.

23. Craven, P. A., J. Pfanstiel, R. Saito, and F. R. DeRubertis. 1987. Actions of sulphasalazine and 5-aminosalicylic acid as reactive oxygen scavengers in the suppression of bile acid-induced increases in colonic epithelial cell loss and proliferative activity. Gastroenterology. 92:1998-2008.

24. Kvietys, P. R., S. M. Smith, M. B. Grisham, and E. A. Manci. 1988. 5-Aminosalicylic acid protects against ischemia/reperfusion-induced gastric bleeding in the rat. Gastroenterology. 94:733-738.

25. Olson, C. E., P. Geshelin, and A. H. Soll. 1987. Hydrogen peroxide increases short circuit current in a cultured colon crypt cell line. Fed. Proc. 46:547. (Abstr.)

26. Hemler, M. E., H. W. Cook, and W. E. M. Lands. 1979. Prostaglandin biosynthesis can be triggered by lipid peroxides. Arch. Biochem. Biophys. 193:340-345.

27. Hemler, M. E., and W. E. M. Lands. 1980. Evidence for a peroxide-initiated free radical mechanism of prostaglandin biosynthesis. J. Biol. Chem. 255:6253-6261.

28. Weiss, S. J., J. Turk, and P. Needleman. 1979. A mechanism for the hydroperoxide-mediated inactivation of prostacyclin synthetase. Blood. 53:1191-1196.

29. Marshall, P. J., and W. E. M. Lands. 1986. In vitro formation of activators for prostaglandin synthesis by neutrophils and macrophages from humans and guinea pigs. J. Lab. Clin. Med. 108:525-534.

30. C. Stendahl, L. Molin, and M. Lindroth. 1983. Granulocytemediated release of histamine from mast cells: effect of myeloperoxidase and its inhibition by antiinflammatory sulfone compounds. Int. Arch. Allergy Appl. Immunol. 70:277-284.

31. Coble, B. I., M. Lindroth, L. Molin, and O. Stendahl. 1984. Histamine release from mast cells during phagocytosis and interaction with activated neutrophils. Int. Arch. Allergy Appl. Immunol. 75:3237.

32. Henderson, W. R., E. Y. Chi, and S. J. Klebanoff. 1980. Eosinophil peroxidase-induced mast cell secretion. J. Exp. Med. 152:265279.

33. Chi, E. Y., and W. R. Henderson. 1984. Ultrastructure of mast cell degranulation induced by eosinophil peroxidase: use of diaminobenzidine cytochemistry by scanning electron microscopy. J. Histochem. Cytochem. 32:337-341.

34. Taylor, L., M. J. Menconi, and P. Polgar. 1983. The participation of hydroperoxides and oxygen radicals in the control of prostaglandin synthesis. J. Biol. Chem. 258:6855-6857.

35. Berschneider, H. M., and D. W. Powell. 1989. Fibroblasts mediate intestinal secretory response to bradykinin, $\mathrm{H}_{2} \mathrm{O}_{2}$ and serotonin. Gastroenterology. 96:A41. (Abstr.)

36. Baud, L., J. Hagege, J. Sraer, E. Rondeau, J. Perez, and R. Ardaillou. 1983. Reactive oxygen production by cultured rat glomerular mesangial cells during phagocytosis is associated with stimulation of lipoxygenase activity. J. Exp. Med. 158:1836-1852. 
37. Harlan, J. M., and K. S. Callahan. 1984. Role of hydrogen peroxide in the neutrophil-mediated release of prostacyclin from cultured endothelial cells. J. Clin. Invest. 74:442-448.

38. Lewis, M. S., R. E. Whatley, P. Cain, T. M. McIntyre, S. M. Prescott, and G. A. Zimmerman. 1988. Hydrogen peroxide stimulates the synthesis of platelet-activating factor by endothelium and induces endothelial cell-dependent neutrophil adhesion. J. Clin. Invest. 82:2045-2055.

39. Nathan, C. F. 1987. Neutrophil activation on biological surfaces. Massive secretion of hydrogen peroxide in response to products of macrophages and lymphocytes. J. Clin. Invest. 80:1550-1560.

40. Beeken, W., I. Northwood, C. Beliveau, and D. Gump. 1987.
Phagocytes in cell suspensions of human colon mucosa. Gut. 28:976980.

41. Welsh, M. J., D. M. Shasby, and R. M. Husted. 1985. Oxidants increase paracellular permeability in a cultured epithelial cell line. $J$. Clin. Invest. 76:1155-1168.

42. Shasby, D. M., M. Winter, and S. S. Shasby. 1988. Oxidants and conductance of cultured epithelial cell monolayers: inositol phospholipid hydrolysis. Am. J. Physiol. 255 (Cell Physiol. 24): C781C788.

43. Craven, P. A., J. Pfanstiel, and F. R. DeRubertis. 1986. Role of reactive oxygen in bile salt stimulation of colonic epithelial proliferation. J. Clin. Invest. 77:850-859. 